кuLTura- MeDia- TeoLogia

ISSN 2081-8971

$2017 \mathrm{nr} 28$, s. 192-208.

\title{
Tematy okładkowe polskich magazynów - elementy składowe i preferencje odbiorców
}

\section{Cover topics in Polish press magazines - their components and preferences of the recipients}

\begin{abstract}
STRESZCZENIE:
OKŁADKI TO JEDEN Z NAJWAŻNIEJSZYCH ELEMENTÓW MAGAZYNÓW. ICH STAEYMI ELEMENTAMI SĄ M.IN. LOGO, TZW. TAGLINES, CENA, NUMER I DATA WYDANIA, KODY KRESKOWE ORAZ TEMATY OKŁADKOWE, WSPÓŁTWORZONE PRZEZ ILUSTRACJE I TEKSTY. W NINIEJSZYM ARTYKULE

AUTORKA BADA REAKCJE ODBIORCÓW NA WYBRANE ELEMENTY SKŁADOWE OKŁADEK (OD ZWRÓCENIA UWAGI NA PISMO, PRZEZ PRZEJRZENIE, ZACHĘCENIE DO KUPNA, AŻ PO PEENE ZNIECHĘCENIE DO JAKIEGOKOLWIEK ZAZNAJOMIENIA SIĘ Z MAGAZYNEM) ORAZ ELEMENTY SKŁADOWE (STOSUNEK DO FOTOGRAFII, GRAFIK I TEKSTÓW). W ARTYKULE ZWERYFIKOWANE ZOSTANĄ TRZY HIPOTEZY: 1) ODBIORCY ODMIENNIE TRAKTUJĄ

ELEMENTY SKŁADOWE TEMATÓW OKŁADKOWYCH;

2) KATEGORIE DEMOGRAFICZNE (TAKIE JAK WIEK, PŁEĆ, ZAMIESZKANIE, WYKSZTAECENIE) ISTOTNIE WPŁYWAJĄ NA PREFERENCJE WZGLĘDEM TEMATÓW OKŁADKOWYCH; 3) TEMATY OKŁADKOWE MAJĄ ZNACZENIE W PROWADZENIU DZIAEALNOŚCI BIZNESOWEJ WYDAWCÓW. PODSTAWĄ TEKSTU SĄ WŁASNE BADANIA ILOŚCIOWE, PRZEPROWADZONE METODĄ ANKIETOWĄ ZA POMOCĄ TECHNIKI CAWI W DN. 2-6 WRZEŚNIA 2016 R. NA ogÓLNOPOLSKIEJ PRÓBIE POLAKÓW N=1094 OSÓB, DOBRANEJ Z PANELU ARIADNA.
\end{abstract}

\section{SŁOWA KLUCZOWE:}

TEMATY OKŁADKOWE, OKŁADKI, MAGAZYNY, PRASA

\begin{abstract}
:
COVERS ARE ONE OF THE MOST IMPORTANT ELEMENTS IN THE MAGAZINE. THEY CONSIST OF LOGO, TAGLINES, PRICE, NUMBER AND DATE OF PUBLICATION, BAR CODES AND COVER TOPICS, CO-CREATED BY ILLUSTRATIONS AND TEXTS. IN THIS ARTICLE, THE AUTHOR EXAMINES TWO TOPICS: FIRST OF ALL, REACTIONS OF THE AUDIENCE (ATTRACTING THE ATTENTION, REVIEWING, BUYING, GIVING UP THE REVIEWING, GIVING UP THE BUYING). SECOND OF ALL COVER'S TOPICS COMPONENTS (APPROACH TO PHOTOGRAPHY, GRAPHICS AND TEXTS). THE ARTICLE VERIFIES THREE HYPOTHESES: 1) RECIPIENTS TREAT THE COVER' TOPICS COMPONENTS DIFFERENTLY; 2) DEMOGRAPHIC CATEGORIES (SUCH AS AGE, GENDER, PLACE OF RESIDENCE, EDUCATION) HAVE A IMPORTANT IMPACT ON PREFERENCES FOR COVER TOPICS; 3) COVER TOPICS SHOULD BE SIGNIFICANT FOR PUBLISHING BUSINESS. THE FOUNDATIONS OF THE PRESENTED TEXT ARE QUANTITATIVE SURVEYS, CONDUCTED BY CAWI (Computer Assisted Web Interviews). They Were CONDUCTED ON SEPTEMBER 2-6TH, 2016 ON A NATIONWIDE SAMPLE OF Poles COUNTING N $=1094$ PEOPLE, SELECTED FROM ARIADNA PANEL.
\end{abstract}

\section{KEYWORDS:}

ICOVER TOPICS, COVERS, MAGAZINES, PRESS 


\begin{abstract}
utorka podejmuje próbę przeprowadzenia szczegółowej analizy odbioru okładek 1 polskich magazynów przez czytelników. Jej decyzja wynika nie tylko z osobistych zainteresowań, ale także z pragnienia uzupełnienia literatury specjalistycznej poświęconej temu tematowi.
\end{abstract}

\title{
Wprowadzenie metodologiczne
}

Biorąc pod uwagę inne tematy związane z medioznawstwem, zauważa się, że marketingowe ujęcie problematyki okładek czasopism wydaje się być zbadane w Polsce dość powierzchownie (mowa o analizie naukowej). Rzutuje to na dobór literatury dla niniejszego artykułu, tym bardziej, że autorka zrezygnowała z cytowania niezliczonej liczby artykułów poświęconych rankingom najlepszych lub najgorszych okładek lub gwiazdom popkultury na okładkach, uznając je bardziej za materiał rozrywkowy, a nie - w kontekście przyjętego obszaru badawczego - za źródło merytorycznej wiedzy. Zamiast tego postanowiła skoncentrować się na wybranej literaturze zagranicznej i wybranych raportach rynkowych, dotyczących głównie nawyków odbiorców. Podstawą tekstu są własne badania ilościowe, przeprowadzone metodą ankietową za pomocą techniki CAWI (tzw. Computer Assisted Web Interviews). Zrealizowano je w dniach 2-6 września 2016 roku na ogólnopolskiej próbie Polaków liczącej $\mathrm{N}=1094$ osób, dobranej z panelu Ariadna ${ }^{1}$. Kwestionariusz ankiety, poświęconej frontowym okładkom i e-okładkom magazynów, składał się z siedemnastu pytań: czterech o cechy społeczno-demograficzne respondenta (płeć, wiek, miejsce pochodzenia, wykształcenie) i kolejnych trzynastu, badających takie zagadnienia, jak:

1. Czytelnictwo prasy drukowanej i elektronicznej;

2. Preferencje respondentów co do formy okładek (elektronicznych lub drukowanych);

3. Zadania okładek drukowanych i elektronicznych;

4. Oddziaływanie okładek drukowanych i elektronicznych na zachowania odbiorców (od zwrócenia uwagi, przez przejrzenie zawartości, aż do kupna);

5. Zakres oddziaływania elementów budowy okładek drukowanych i elektronicznych (od zwrócenia uwagi, przez przejrzenie zawartości, aż do kupna);

6. Wpływ doboru tematów okładkowych na decyzje zakupowe odbiorców (od zwrócenia uwagi, przez przejrzenie zawartości, aż do kupna);

7. Sposób oglądania okładek przez odbiorców (określenie kolejności, w której poszczególne fragmenty powierzchni okładek najbardziej przyciąają uwagę Polaków).

Większość pytań miała charakter zamknięty (czternaście jednokrotnego wyboru i dwa kafeteryjne), a jedno było otwarte. Należy zaznaczyć, że każde z tych pytań przeanalizowano w kontekście wymienionych powyżej kategorii demograficznych. Na potrzeby artykułu autorka wybrała fragmenty badań związane z jego tytułem, koncentrując się na reakcji polskich odbiorców na tematy okładkowe.

$1 \quad$ https://panelariadna.pl/userpanel.php, dostęp: 15.05.2017. 


\section{OBLICZA MEDIÓW}

Celem niniejszego artykułu wobec tego jest przedstawienie:

- $\quad$ roli i formy tematów okładkowych;

- $\quad$ preferencji odbiorców względem tematów okładkowych (w tym ich komponentów);

- $\quad$ wpływu kategorii demograficznych na odbiór tematów okładkowych.

Autorka sformułowała następujące hipotezy:

- $\quad$ odbiorcy odmiennie traktują elementy składowe tematów okładkowych (to jest tekst, grafikę i zdjęcia);

- $\quad$ kategorie demograficzne (takie jak wiek, płeć, zamieszkanie, wykształcenie) istotnie wpływają na preferencje względem tematów okładkowych;

- tematy okładkowe mają znaczenie w prowadzeniu działalności biznesowej wydawców.

\section{Tematy okładkowe - rola i forma występowania}

Okładki to jeden z najważniejszych elementów współczesnych magazynów. Bardzo często - szczególnie, gdy budzą kontrowersje albo szokują - są przedmiotem działań promocyjnych wydawców, wypowiedzi komentatorów czy odbiorców ${ }^{2}$.

Funkcje okładek można zdefiniować jako ochronne (zabezpieczenie zawartości pisma przez urazami mechanicznymi), relacyjne (pobudzające do rozmów, wyrażania opinii na ich temat), ideologiczne (kulturotwórczo-edukacyjne, bo niekiedy przedstawiające istotne społecznie treści, np. kwestie równouprawnienia ze względu na kolor skóry czy płeć), innowacyjne (wprowadzające nowoczesne technologie do ich tradycyjnych i cyfrowych wydań, np. wideo lub dźwięk), sprzedażowe (przekładające się na pośrednią lub bezpośrednią sprzedaż magazynu) oraz informacyjno-promocyjne (z jednej strony budujące wizerunek pisma ze względu na eskpozycję jego identyfikacji wizualnej, a także dobór i prezentację zapowiedzi artykułów wewnątrz wydania; z drugiej zaś - kreujące wizerunek osób, zjawisk czy produktów, które na tych okładkach się znajdują) ${ }^{3}$.

2 Okładki są stałym elementem promocji magazynu. W momencie, gdy pojawia się jego kolejny numer albo gdy na rynek wprowadzane jest nowe pismo, zawsze wyeksponowana zostaje okładka (w formie zdjęciowej i często przy wsparciu informacji prasowych). Na przykład „Gazeta Polska” wydanie numeru 20 z 17 maja 2017 roku promowała poprzez eskpozycję okładki na swoje stronie internetowej (z 16.05.2017 r., http://www.gazetapolska.pl dostęp 18.05.2017 r.), koncie na Twitterze (z 16.05.2017 r., godz. 13.02, https://twitter.com/GPtygodnik, dostęp 18.05.2017 r.) i profilu na Facebooku (z 16.05.2017 r.,

https://www.facebook.com/GPCodziennie/, dostęp 18.05.2017 r.). Kontrowersyjna okładka, będąca zapowiedzią artkułu wiążącego tragiczną śmierć Magdaleny Żuk ze środowiskiem politycznym, stała się obiektem doniesień medialnych (por. Nocne kluby, w których bywają politycy PO.... To niewiarygodne, ale „Gazeta Polska” upolityczniła śmierć Magdaleny Żuk, NaTemat.pl z 17.05.2017 r.,

http://natemat.pl/208251,nocne-kluby-w-ktorych-bywaja-politycy-po-to-niewiarygodne-ale-gazeta-polska-upolitycznila-smierc-magdaleny-zuk, dostęp 18.05.2017 r.) i krytyki czytelników (por. M. Fijewska, „Jesteście podli!’”. Okladka z Magdaleną Żuk wywołała burzę, Wp.pl z 17.05.2017, http://wiadomosci.wp.pl/jestescie-podli-okladka-z-magdalena-zuk-wywolala-burze-6123340667676801a, dostęp 18.05.2017 r.). 
W kontekście tego artykułu należy zwrócić uwagę na ostatnią funkcję okładki, ponieważ pojawia się tam sformułowanie dotyczące „doboru i prezentacji artykułów wewnątrz wydania”. Mowa oczywiście o tematach okładkowych, które pełnią rolę informacyjną (zapowiadając treść danego wydania), autopromocyjną (zwracając uwagę odbiorcy na magazyn, zachęcając do przejrzenia jego zawartości lub zakupu danego wydania, a w szerszym ujęciu - kreując jego wizerunek), promocyjną (wpływając na wizerunek osób czy instytucji pojawiających się w tematach okładkowych).

Jaką formę przyjmuje temat okładkowy? Aby odpowiedzieć na to pytanie, należy wskazać stałe elementy budowy okładek. David E. Sumner i Shirrel Rhoades wyróżniają tu: tytuł (wraz z logo), hasła przewodnie marki (tzw. taglines: inaczej slogany w kilku słowach precyzujące cel wydawania magazynu), kod kreskowy, adres strony WWW, cenę, datę wydania, elementy graficzne poza logo (zdjęcia lub ilustracje) i tzw. cover lines (krótkie teksty pojawiające się na okładkach wyjaśniające zawartość danego numeru magazy$\mathrm{nu})^{4}$ lub teaser lines (krótkie, słowne opisy treści artykułów z danego numeru) ${ }^{5}$. Ci sami autorzy wskazują cztery typy projektowania okładek: 1) pojedynczą ilustrację i pojedynczy opis słowny; 2) pojedynczą ilustrację i wiele opisów słownych; 3) wiele ilustracji i wiele opisów słownych; 4) same ilustracje lub samą typografię ${ }^{6}$. Jak widać, aż w trzech przypadkach dochodzi do łączenia obrazu i tekstu, co z kolei Ellen McCracken ujmuje jako „złożony, semiotyczny system, komunikujący (...) znaczenia za pomocą języka, fotografii, grafiki, koloru i umiejscowienia"?. Wspomniani autorzy poradnika dla dziennikarzy, Sumner i Miller, radzą też, aby nie rozdzielać elementów graficznych i tekstowych. Sugerują, by treść artykułu była dopasowana nie tylko do specyfiki pisma, ale i jego okładki (a ściślej: „twarzy” na okładce i zapowiedzi tekstowej) ${ }^{8}$. O zdjęciach („najlepszych dla najlepszego tematu”) i tekstach (które „mają porywać”) pisze także Leszek Waligóra z „Głosu Wielkopolskiego" dodając, że na okładce:

- winien się znajdować jeden temat główny, od jednego do trzech mniejszych oraz „kilka bardzo krótkich «zajawek» tego co w środku”;

3 Tematowi zadań, jakie pełnią okładki w magazynach, autorka poświęciła osobny artykuł (zob. A. Jupowicz-Ginalska, Zadania okładek współczesnych magazynów drukowanych, , Rocznik Bibliologiczno-Prasoznawczy” $2017 \mathrm{nr} 20$ - obecnie w druku). Tutaj, ze względu na przyjęty obszar badawczy, jedynie odniosła się do funkcji opisywanego elementu pisma, co było jednak konieczne ze względu na definiowanie terminu ,temat okładkowy”.

4 L. Thompson, Cover Story: Have You Got What It Takes to Be a Magazine Editor?, Mankato MN 2009, s. 8.

5 D. E. Sumner, S. Rhoades, Magazines: A Complete Guide to the Industry, Nowy Jork 2006, s. 47-54.

6 Tamże, s. 51.

7 E. McCracken, Decoding Women's Magazines: From Mademoiselle to Ms., Houndmills-Basingstoke, Hampshire-Londyn 1993, s. 13. Badaczka zauważa także, że okładka „oferuje czytelnikom silną, ale nieobowiązkową ramę interpretacyjną dla tego, co za nią podąża” (s. 32). Rolę tę mogą pełnić głównie tematy okładkowe jako graficzno-tekstowe komunikaty przesycone treścią.

8 D. E. Sumner, H. G. Miller, Feature and Magazine Writing: Action, Angle and Anecdotes, Chichester WS 2009, s. 81.

$9 \quad$ L. Waligóra, Jak zrobić dobrą jedynkę?, Juniormedia.pl (brak daty opubl.), http://www.juniormedia.pl/wp-content/uploads/2013/07/Jakzrobicdobrajedynke.pdf (dostęp 


\section{OBLICZA MEDIÓW}

- nie należy wymieniać wszystkich artykułów, tylko wyselekcjonować te, które zwrócą uwagę odbiorcy.

Z powyższych wypowiedzi wynika, że ważną rolę dla okładek magazynów pełnią wspomniane cover lines i grafiki (w które nie wlicza się logo, które - ze względu na niepodważalną rolę, jaką pełni w komunikacji marketingowej - winno być traktowane osobno, a nie jako element tematu okładkowego). Można zatem stwierdzić, że obydwa elementy - spośród pozostałych stałych części składowych okładek - w pełni realizują zadanie informowania o zawartości pisma i jednocześnie zachęcania do interakcji z nim. Tematy okładkowe, których w gruncie rzeczy dotyczyła przecież przytoczona klasyfikacja Sumnera i Rhoades ${ }^{10}$, przyjmują więc formę ilustracyjną (zdjęciową albo graficzną) i tekstową $a^{11}$.

\section{Elementy składowe tematów okładkowych a preferencje odbiorców - dane a kategorie demograficzne} Jak zauważono, na tematy okładkowe mogą składać się zdjęcia, grafika i teksty ${ }^{12}$. W przeprowadzonej ankiecie respondenci mieli wskazać, na który z tych elementów zwracają największą uwagę. Celem niniejszego podrozdziału jest więc przedstawienie wyników charakteryzujących stanowisko Polaków w powyżej wskazanym zakresie.

Uśrednione dane były jednoznaczne: okazało się, że 44,5\% ankietowanych najmocniej reaguje na okładkowe zdjęcia, na grafikę - 38,6\%, a na teksty $16,6 \%$. Wyniki te różnicują się jednak, jeżeli przeanalizuje się je przez pryzmat kategorii demograficznych.

Biorąc pod uwagę płeć, należy podkreślić, że kobiety są nieco bardziej wrażliwe na słowo pisane - reaguje na nie $19,3 \%$ Polek (na ten element okładki wskazuje tylko 13,6\% panów). Chętniej niż mężczyźni wybierają zdjęcia (48,5\% respondentek i 40,8\% respondentów). Z kolei panowie preferują grafikę (tę odpowiedź wybrało 45,6\% panów,

\subsubsection{7 r.).}

10 Autorzy nie odnosili się wówczas do innych, wymienionych wcześniej, elementów okładki.

11 Warto zaznaczyć, że niektórzy autorzy wśród typów okładek wymieniają tzw. poster covers. Definiuje się je jako okładki bez tekstów (w tym także bez cover lines). Ich zadaniem jest niekoniecznie nawiązywanie do treści magazynu, lecz kreowanie pewnego nastroju wokół wydania (szczególnie miało to miejsce na przełomie XIX i XX wieku); por. S. Johnson, P. Prijatel, Magazine Publishing; Lincolnwood IL 2000, s. 241. Z kolei Gerald Grow widzi je jako okładki eksponujące wyjątkowe zdjęcia lub ilustracje, gdzie umieszczenie cover lines jest możliwie, ale na drugim planie. Ten sam autor twierdzi jednak, że obecnie okładki plakatowe są rzadkością, a częstym elementem okładek stały się zapowiedzi tekstowe. Por. G. Grow, Magazine Covers and Cover Lines: An Illustrated History, "Journal of Magazine \& New Media Research", Vol. 5, No. 1, 2002, s. 4 i 16.

W opisywanej ankiecie wzięto pod uwagę także reakcje odbiorców ze względu na np. działanie tekstów, charakter zdjęcia (sesyjne, reporterskie, fotomontaż), jego ekspozycję (główne, wspierające) czy grafikę. Pozyskane dane również przeanalizowano w kontekście kategorii demograficznych oraz reakcji (budzenie zainteresowania, przeglądanie, kupno, zniechęcenie). Autorka postanowiła jednak przedstawić te dane w osobnym artykule, a tutaj skupiając się wyłącznie na tematach okładkowych. Wśród przyczyn takiej decyzji należy wskazać troskę o przejrzystość prezentowanych tu danych. Prócz wspominanych zdjęć, grafik i tekstów elementami okładek są także np. logo pisma, cena, kod QR, odnośnik do strony www lub adresu na medium społecznościowym czy ewentualne zafoliowane. Te elementy również przebadano w ankiecie i warto zaprezentować je w jednym, spójnym tekście związanym z ich postrzeganiem przez Polaków. 
a pań $32,2 \%$, co jest znaczną różnicą w porównaniu do uśrednionych danych). Nasuwa się tu od razu pierwszy wniosek: temat okładkowy w magazynach męskich powinien bazować na grafice ze wsparciem zdjęciowym, zaś teksty winny grać najmniejszą rolę. Okładki pism kobiecych muszą zaś zawierać fotografie i w mniejszym stopniu grafikę, natomiast teksty powinny być nieco bardziej wyeksponowane.

Do ciekawych wniosków można dojść, analizując wyniki badań związanych z kategorią wiekową (rysunek 1). Najmłodsi badani najczęściej wybierają grafikę (67\% w wieku 18-24 lata i 48,3\% w wieku 25-34 lata). W obydwu grupach zdjęcia i teksty są na kolejnych miejscach, chociaż największe różnice między odpowiedziami widać właśnie wśród najmłodszych (zdjęcia wybiera zaledwie 19,1\%). Preferowanie obrazu graficznego (kosztem słowa) w komunikacji piśmiennej to jedna z cech charakterystycznych pokolenia Millennialsów i generacji $\mathrm{Z}^{13}$, zauważalna także w ich podejściu do okładek frontowych. Starsze pokolenia częściej wybierają zdjęcia (szczególnie w wieku 35-44 lata i 45-54 lata), a rola tekstu wzrasta wraz z wiekiem (aż $23,5 \%$ respondentów $55+$ wybrało słowo pisane, a grafikę - 28,6\%, i jest to najlepszy wyniki dla tekstów w całym badaniu).

Wyniki badań ze względu na wyedukowanie odbiorców przedstawia rysunek 2. W grupie osób z wykształceniem podstawowym najpopularniejsza jest grafika (56\% wskazań), której rola spada wraz z finalizowaniem kolejnych etapów edukacji (dane dla wykształcenia średniego i wyższego oscylują w okolicy 36-37\%). Co ciekawe, wybrało ją zaledwie $21,8 \%$ po zawodówce. Dla nich, podobnie zresztą jak i dla osób lepiej wykształconych, dużo ważniejsze są zdjęcia i to nimi powinni operować wydawcy przy konstruowaniu projektów okładek frontowych. A co z tekstem? Najgorzej wypada on wśród Polaków po podstawówce (12,2\%), potem jego rola rośnie wraz z wykształceniem (do 19\% dla absolwentów szkół wyższych).

Jeżeli chodzi o wpływ miejsca zamieszkania na odpowiedzi respondentów (rysunek 3), to mieszkańcy wsi najrzadziej wybierają teksty na okładkach: potem ich rola rośnie wraz z wielkością miejsca zamieszkania - za wyjątkiem wielkich miast, które w tym zakresie odnotowują wynik niewiele wyższy niż reprezentanci obszarów wiejskich. Być może wynika to z pośpiechu, w którym żyją badani pochodzący z aglomeracji miejskich? Wszak przeczytanie tekstu na okładce - któremu towarzyszy przytłaczająca liczba bodźców - jest trudniejsze niż szybki rzut oka na zdjęcie czy też grafikę. Należy podkreślić, że to właśnie zdjęcia pełnią najważniejszą rolę wśród mieszkańców małych, średnich i wielkich miast (notując wyniki między 45,7\% a 51,7\%), z kolei rola grafiki rośnie wśród

13 Dan Schawbel z Millennial Branding stwierdził wręcz: „Mówimy swoim partnerom biznesowym, że jeżeli nie wyrażą się w pięciu słowach i dużym obrazie, to nie trafią do tej generacji”, por. A. Williams, Move over, Millennials, here comes Generation Z, The New York Times.com z 18.09.2015 r., lhttps://www.nytimes.com/2015/09/20/fashion/move-over-millennials-here-comes-generation-z.html? _r=0 (dostęp 19.05.2017 r.); R. Scott, Get Ready For Generation Z, Forbes.com z 28.11.2016 r., https://www.forbes.com/sites/causeintegration/2016/11/28/get-ready-for-generation-z/\#277168272204 (dostęp 19.05.2017 r.). James Emery White dodaje, że np. Generacja Z jest zorientowana na komunikację wizualną, a wiedzę o świecie zdobywa poprzez YouTube, Netlix i wszystko to, co uzna za wizualnie atrakcyjną (por. J.E. White, Meet Generation Z: Understanding and Reaching the New Post-Christian World, Waszyngton 2017. 


\section{OBLICZA MEDIÓW}

mieszkańców wsi i dużych miast (odpowiednio 43\% i 39,8\% - w obydwu przypadkach poziom wskazań jest właściwy niemal równy wskazaniom zdjęć).

Biorąc pod uwagę przedstawione rezultaty badań, można stwierdzić, że kategorią demograficzną najsłabiej różnicującą wyniki jest miejsce zamieszkania (wyłączając jednak wieś), najmocniej czynią to wiek i wykształcenie. Nie da się ukryć, że najgorzej we wskazaniach wypada tekstowy element tematów okładkowych, chociaż jego udział rośnie wraz z wyksztalceniem, wiekiem i miejscem zamieszkania. Grafika najlepiej przyjmuje się wśród osób najmłodszych, z podstawowym wykształceniem i pochodzących ze wsi. Zdjęcia zaś preferowane są przez osoby ze starszych grup docelowych, a także tych po zawodówce oraz z małych i średnich miast. Należy też dodać, że na czele większości zestawień są - poza małymi wyjątkami - fotografie.

Jak widać, nawet badania okładek udowadniają, że ludzie najlepiej reagują na bodźce obrazowe, a szczególnie fotografie. Rozumieją to wydawcy, którzy kładą coraz większy nacisk na „widoczne zwiększanie udziału fotografii w objętości pisma”, ponieważ „zdjęcie oprócz informowania, budowania wiedzy oraz wpływania na emocje, musi ozdabiać tekst, uzupełniać go i uatrakcyjniać (...) we współczesnej prasie określenie wspomnianej roli jako wyłącznie estetycznej jest niewystarczające. Dziś rola ta zamienia się w funkcję marketingową, której zadaniem jest dobrze «sprzedać» tytuł"14.

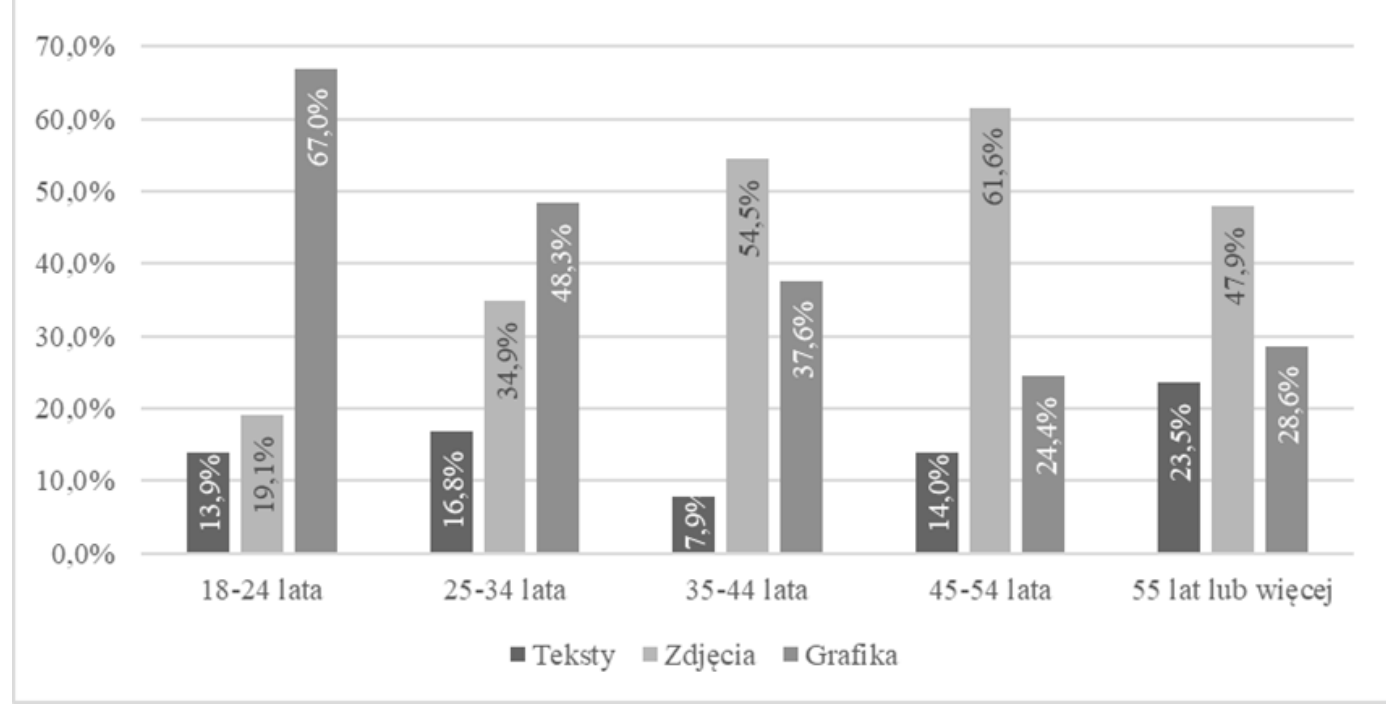

Rysunek 1. Elementy składowe tematów okładkowych a preferencje odbiorców (dane szczegółowe - wiek)

Źródło: opracowanie własne na podstawie badań przeprowadzonych na ogólnopolskiej próbie liczącej N=1094 osób, dobranej z panelu Ariadna metodą CAWI. Odpowiadający: wszyscy badani.

14 J. Szylko-Kwas, Fotografią po oczach. O fotografii na pierwszej stronie „Gazety Wyborczej” i „Rzeczpospolitej”, „Studia Medioznawcze” 2011 z. 44, s. 139 i 141. 


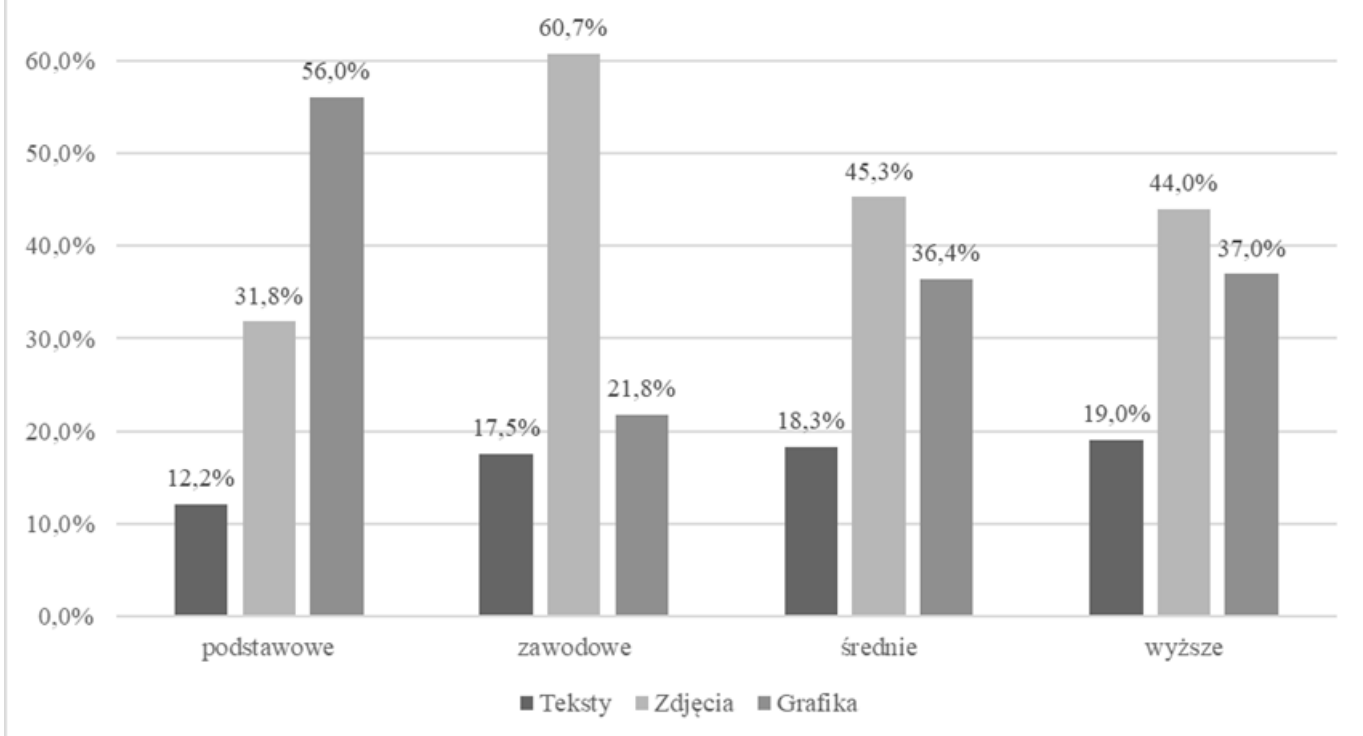

Rysunek2. Elementy składowe tematów okładkowych a preferencje odbiorców (dane szczegółowe - wykształcenie). Źródło: opracowanie własne na podstawie badań przeprowadzonych na ogólnopolskiej próbie liczącej N=1094 osób, dobranej z panelu Ariadna metodą CAWI. Odpowiadający: wszyscy badani.

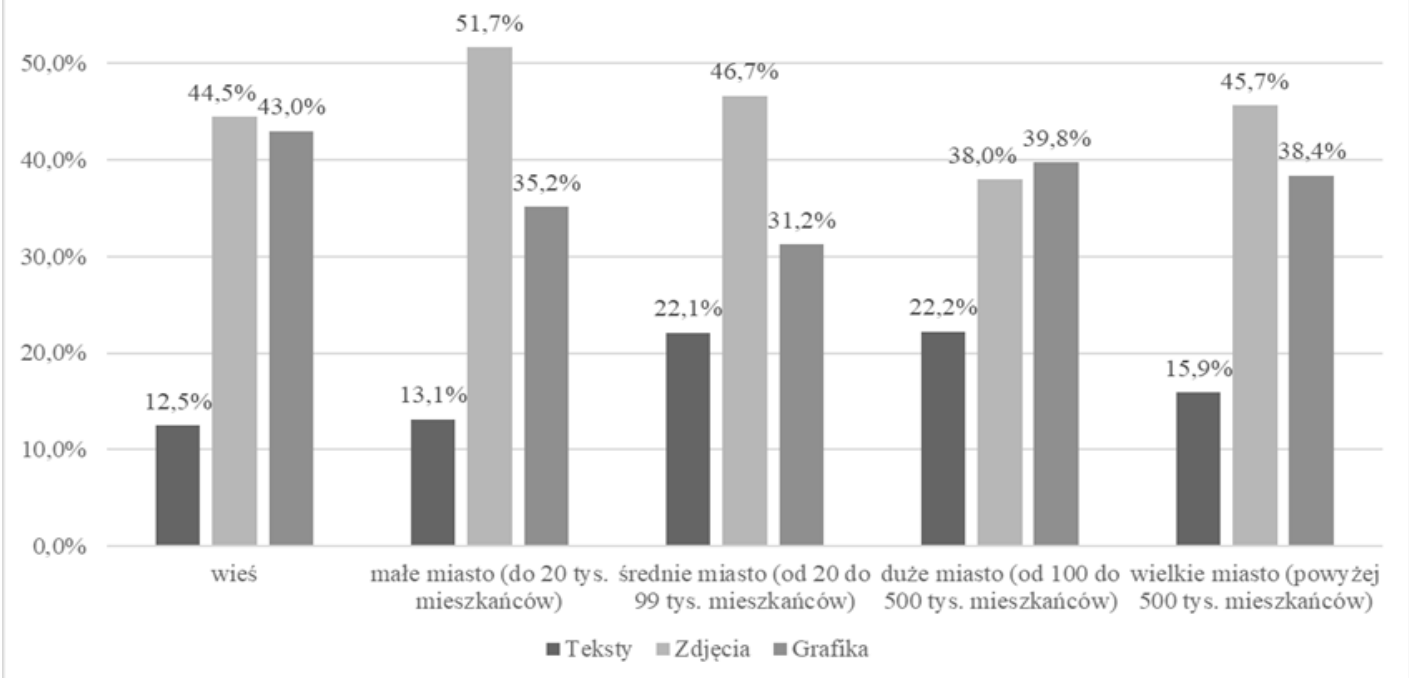

Rysunek 3. Elementy składowe tematów okładkowych a preferencje odbiorców (dane szczegółowe - miejsce zamieszkania). Źródło: opracowanie własne na podstawie badań przeprowadzonych na ogólnopolskiej próbie liczącej N=1094 osób, dobranej z panelu Ariadna metodą CAWI. Odpowiadający: wszyscy badani. 


\section{OBLICZA MEDIÓW}
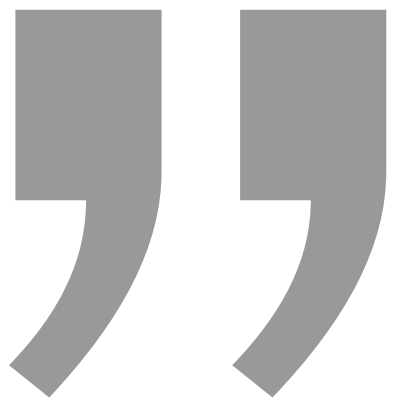

Okazuje się, że niemal 1/3 badanych zwraca uwagę na tematy okładkowe, a dalsze 29\% przeglądają pismo pod ich wpływem. Kolejne 23\% decyduje się od razu na zakup magazynu. Co ważne, niemal 18,5\% potwierdza negatywne działanie tego elementu okładki, wyrażone w postaci zniechęcenia do przejrzenia lub zakupu pisma.

\section{Związek tematów okładkowych z reakcjami odbiorców}

W niniejszym podrozdziale autorka przeanalizowała reakcje odbiorców na tematy okładkowe (wszystkie dane przedstawiono najpierw w formie uśrednionej, potem w kontekście płci, wieku, wykształcenia i miejsca pochodzenia respondentów). By zbadać tę problematykę, postawiono następujące pytania badawcze:

- czy tematy okładkowe wzbudzają zainteresowanie odbiorców?

- czy tematy okładkowe zachęcają do przeglądania magazynów?

- czy tematy okładkowe przekładają się bezpośrednio na sprzedaż magazynów?

- czy tematy okładkowe zniechęcają odbiorców do kupna lub przejrzenia magazynów?

\section{a. Dane uśrednione}

Na rysunku 4 przedstawiono uśrednione dane. Okazuje się, że niemal 1/3 badanych zwraca uwagę na tematy okładkowe, a dalsze $29 \%$ przegląda pismo pod ich wpływem. Kolejne $23 \%$ decyduje się od razu na zakup magazynu. Co ważne, niemal 18,5\% potwierdza negatywne działanie tego elementu okładki, wyrażone w postaci zniechęcenia do przejrzenia lub zakupu pisma. Widać więc, że generalnie tematy okładowe wiążą się z reakcjami respondentów, przy czym niemal $1 / 5$ wskazuje na ich nieskuteczność $\mathrm{w}$ procesie sprzedażowym. Dość kłopotliwa $\mathrm{z}$ biznesowego punktu widzenia jest też niska liczba wskazań przy pytaniu o bezpośrednią, sprzedażową rolę tematów okładkowych - otrzymane $23 \%$ to niewiele więcej od wyniku oddziaływania niepożądanego (ok. 18,5\%). Być może więc Polacy nie kupują prasy impulsywnie, na zasadzie prostej reakcji na bodziec, jakim w tym przypadku jest temat okładki? Może - co zdają się sugerować wyniki dotyczące zwracania uwagi i przeglądania pisma - wolą najpierw zapoznać się z zawartością wydania, niż ulegać jego opakowaniu? Pocieszającą dla wydawców informacją jest z pewnością fakt, że ponad 80\% Polaków pozytywnie reaguje na tematy okładkowe, głównie je po prostu zauważając. Rolą koncernów prasowych jest wobec tego dopasowanie zarówno formy, jak i treści tematów okładkowych do preferencji swoich czytelników. 


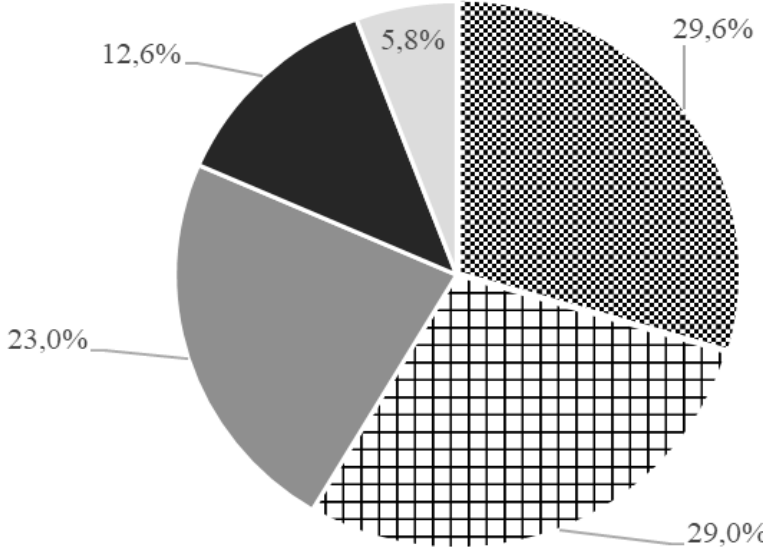

\author{
* Zwracają moją uwagę \\ - Zachęcają mnie do przejrzenia pisma \\ - Zachęcają mnie do kupna pisma \\ - Zniechẹcają mnie do przejrzenia pisma \\ "Zniechęcają mnie do kupna pisma
}

Rysunek 4. Reakcje odbiorców na tematy okładkowe polskich magazynów (dane uśrednione). Źródło: opracowanie własne na podstawie badań przeprowadzonych na ogólnopolskiej próbie liczącej N=1094 osób, dobranej z panelu Ariadna metodą CAWI. Odpowiadający: wszyscy badani.

\title{
b. Dane a kategorie demograficzne - płeć, wiek, wykształcenie i miejsce zamieszkania
}

Kobiety dużo chętniej pod wpływem tematów okładkowych przeglądają magazyny, ale kupują je już mężczyźni (rysunek 5). Co ciekawe, panowie znacznie częściej bywają zniechęcani do przeglądania zawartości (do kupna już nie), co oznacza, że nieco szybciej podejmują decyzje związane z zakupem, realizując krótką drogę transakcji z wydawcą na zasadzie: zapoznanie się z tematem okładkowym => zakup magazynu.

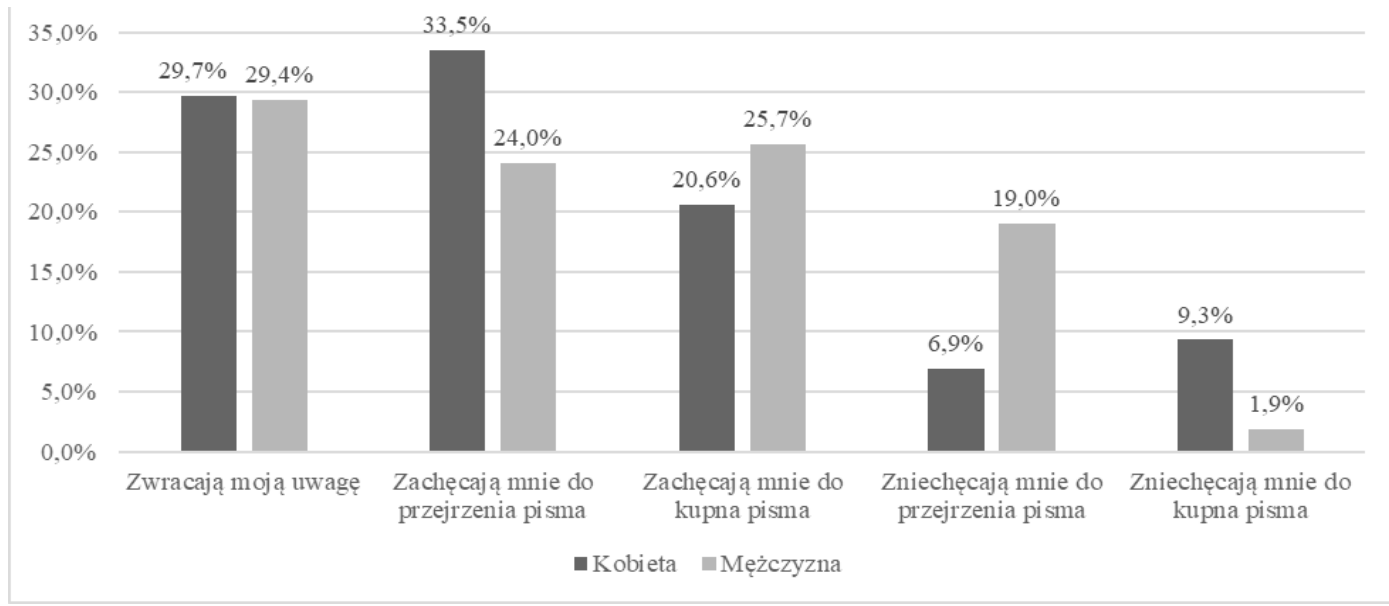

Rysunek 5. Reakcje odbiorców na tematy okładkowe polskich magazynów (dane szczegółowe - płeć). Źródło: opracowanie własne na podstawie badań przeprowadzonych na ogólnopolskiej próbie liczącej $\mathrm{N}=1094$ osób, dobranej z panelu Ariadna metodą CAWI. Odpowiadający: wszyscy badani. 


\section{OBLICZA MEDIÓW}
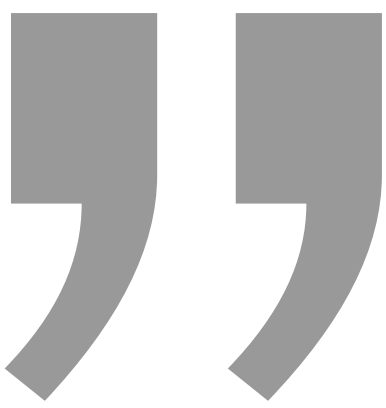

\section{Badani w wieku 45-54 lata sa najlepsza}

dla wydawców grupą docelową, ponieważ z jednej strony zniechęcenie jest tu najniższe, a z drugiej - przedstawiciele tej grupy najchętniej kupują magazyny pod wpływem tematów okładek (33,7\% odpowiedzi), Osoby z grupy 55+ nie są co prawda zniechęcane do kupna, ale robią to dość rzadko (21\%),

Jeśli chodzi o kategorię wiekową (rysunek 6), to najmłodsi generalnie nie kupują magazynów (ani nie bywają zniechęceni do ich kupna) na podstawie tematów okładkowych. Te działają na nich głównie jako element pisma, który zwraca uwagę, nie przekłada się jednak na ani decyzje zakupowe, ani nawet na przejrzenie (prawie 33\% badanych stwierdziło, że tematy okładkowe zniechęcają ich do sięgnięcia po magazyn). Można tu wskazać dwa wyjaśnienia: albo tematy nie są sformułowanie pod kątem oczekiwań tej grupy czytelniczej, albo - i to ujęcie z szerszej perspektywy, związanej z nawykami czytelniczymi Polaków - młodzi powoli odchodzą od prasy drukowanej, głównie na rzecz Internetu ${ }^{15}$. Respondenci w wieku 25-34 lata nie są zniechęceni tematami okładkowymi, w związku z czym reagują na nie pozytywnie - nie tylko je zauważając, ale też sięgając po magazyn oraz - nieco rzadziej - decydując się na jego kupno. Osoby w wieku 35-44 lata są kłopotliwą grupą odbiorców, ponieważ wzrasta tu poziom wskazań potwierdzających zniechęcenie tematami okładkowymi (tradycyjnie Polacy zauważają tematy okładkowe, potem ewentualnie przeglądają pismo, ale kupują już w najmniejszym stopniu robi tak tylko ok. 18\%). Badani w wieku 45-54 lata są najlepszą dla wydawców grupą docelową, ponieważ z jednej strony zniechęcenie jest tu najniższe, a z drugiej - przedstawiciele tej grupy najchętniej kupują magazyny pod wpływem tematów okładek (33,7\% odpowiedzi). Osoby z grupy 55+ nie są co prawda zniechęcane do kupna, ale robią to dość rzadko (21\%). To ciekawy wynik: tym bardziej, że respondenci przeglądają zawartość pod wpływem tematów okładkowych. Być może niewielki efekt prosprzedażowy wynika $\mathrm{z}$ ograniczeń finansowych tej grupy badanych lub - ponownie - niedopasowania zawartości do specyficznych je j potrzeb?

Co ciekawe, w przypadku kategorii wiekowej trudno wysnuć wnioski jednorodne dla wszystkich grup docelowych (może poza tym, że bezpośrednio prosprzedażowe oddziaływanie tematów okładkowych jest najsłabsze: oprócz osób w wieku 45-54 lata), dlatego też z biznesowego punktu widzenia każda z nich winna być analizowana osobno.

15 Por. A. Perchla-Włosik, J. Wardzała, Młodzi członkowie gospodarstw domowych jako konsumenci mediów masowych w świetle badań jakościowych, „Zeszyty Naukowe Wyższej Szkoły Bankowej we Wrocławiu” 2015 z. 3, s. 401. 


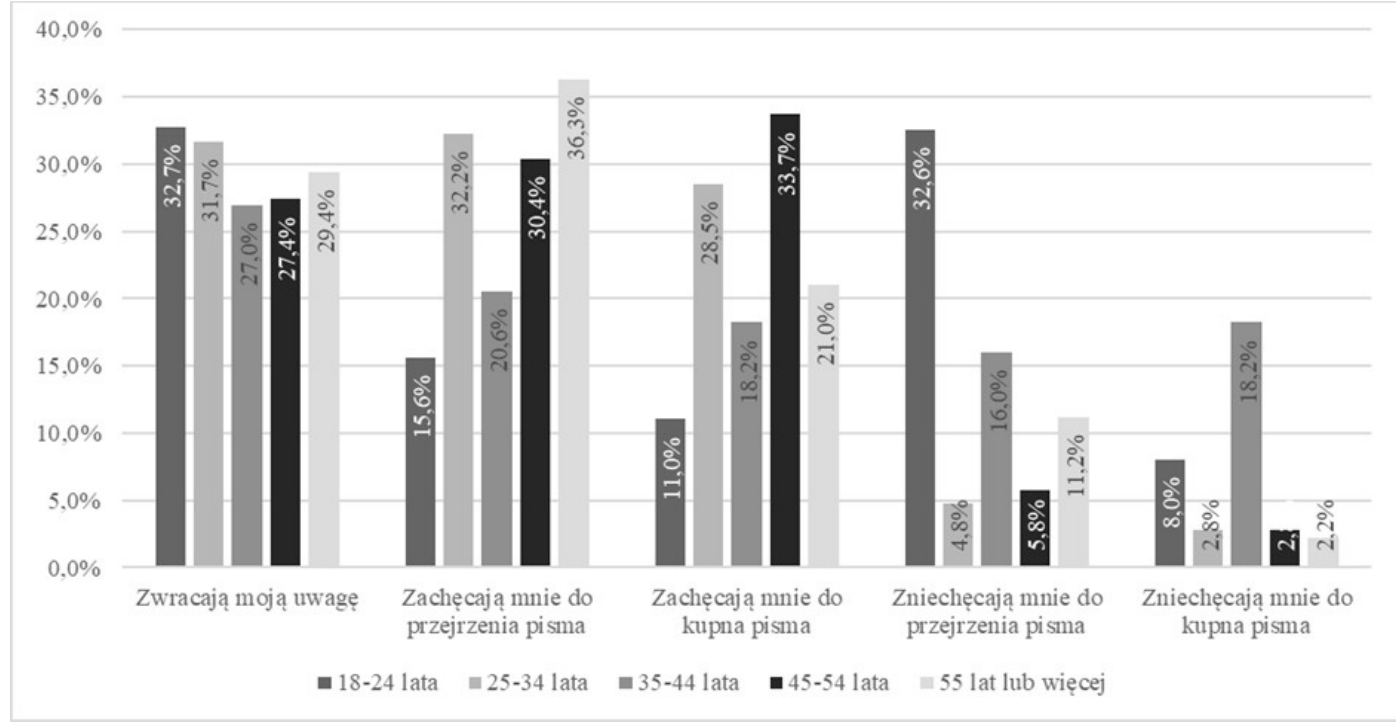

Rysunek 6. Reakcje odbiorców na tematy okładkowe polskich magazynów (dane szczegółowe - wiek). Źródło: opracowanie własne na podstawie badań przeprowadzonych na ogólnopolskiej próbie liczącej N=1094 osób, dobranej z panelu Ariadna metodą CAWI. Odpowiadający: wszyscy badani.

W przypadku kategorii wykształcenia można stwierdzić, że osoby po szkole podstawowej są najczęściej zniechęcone tematami okładkowymi (rysunek 7). Co prawda, zwracają one ich uwagę, ale pozostałe pozytywne wskazania notują wyniki na poziomie maksymalnie $21 \%$. Badani z wykształceniem średnim bywają zniechęcani do przejrzenia pisma, ale do jego zakupu - już nie. Tu Polacy zauważają te tematy (najwięcej wskazań - ponad 35\%), natomiast rzadziej pod ich wpływem prasę przeglądają czy tym bardziej kupują (spadek do ok. $25 \%$ odpowiedzi). Absolwenci szkół wyższych najrzadziej zniechęcają się tematami okładkowymi, a najczęściej zwracają na nie uwagę i przeglądają dzięki nim zawartość magazynów (adekwatnie $35,1 \%$ oraz $35,7 \%$ ). Niestety, na zakup decyduje się już tylko $21 \%$. Badani z wykształceniem zawodowym przeglądają magazyny (ponad 35\%) i - uwaga - je kupują (ponad $30 \%$, co jest najlepszym wynikiem prosprzedażowym w tej kategorii).

W omawianej kategorii demograficznej prosprzedażowa rola tematów okładkowych jest najmniejsza. Wskazanie innych wniosków jednoznacznych dla całej kategorii byłoby zbyt daleko idącym uproszeniem, dlatego też każdą z grup należy analizować osobno. Warto mieć to na względzie, przygotowując zarówno treść, jak i formę tematów okładkowych.

Jeśli zaś chodzi o kategorię miejsca zamieszkania (rysunek 8), to mieszkańcy wsi wykazują zauważalny poziom zniechęcenia do przeglądania pism pod wpływem tematów okładkowych (prawie 18\%). Tu opisywane elementy magazynów najskuteczniej zwracają uwagę respondentów i, w nieco mniejszym stopniu, przekładają się na zakup danego wydania. 


\section{OBLICZA MEDIÓW}

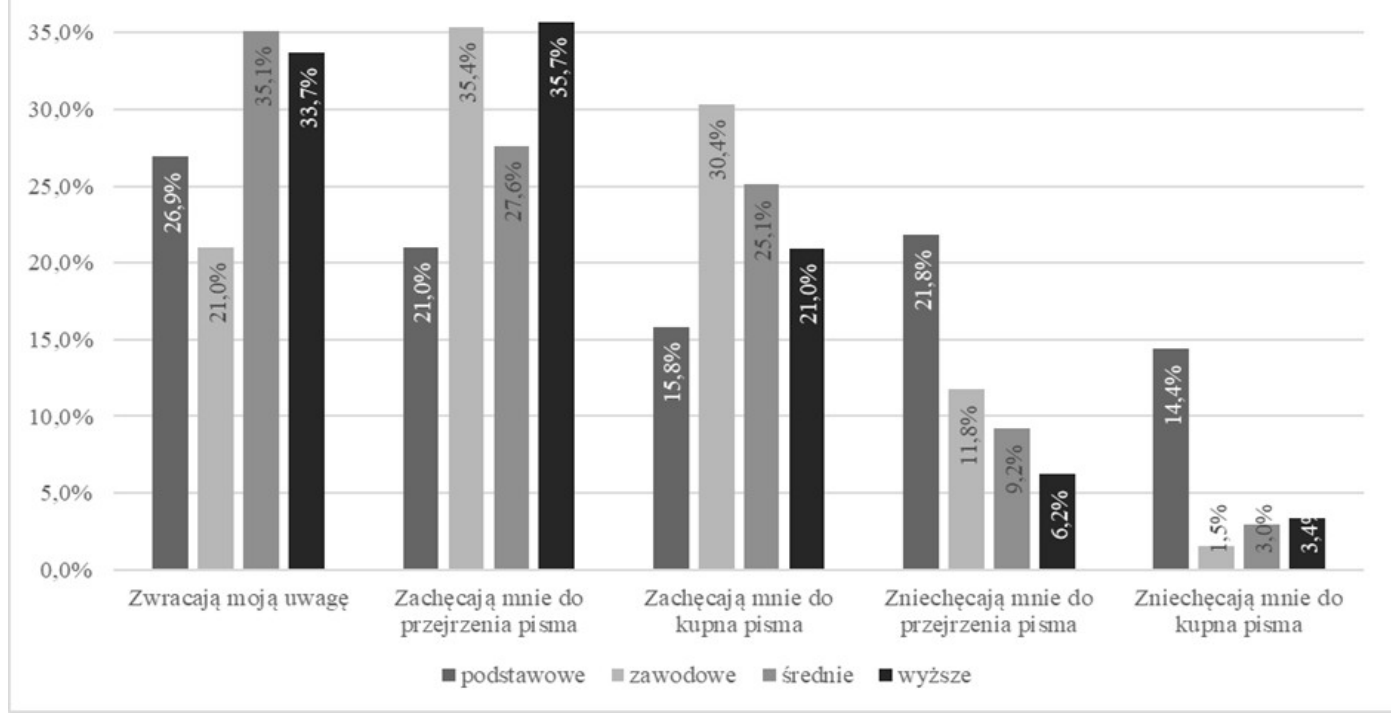

Rysunek 7. Reakcje odbiorców na tematy okładkowe polskich magazynów (dane szczegółowe - wykształcenie). Źródło: opracowanie własne na podstawie badań przeprowadzonych na ogólnopolskiej próbie liczącej N=1094 osób, dobranej z panelu Ariadna metodą CAWI. Odpowiadający: wszyscy badani.

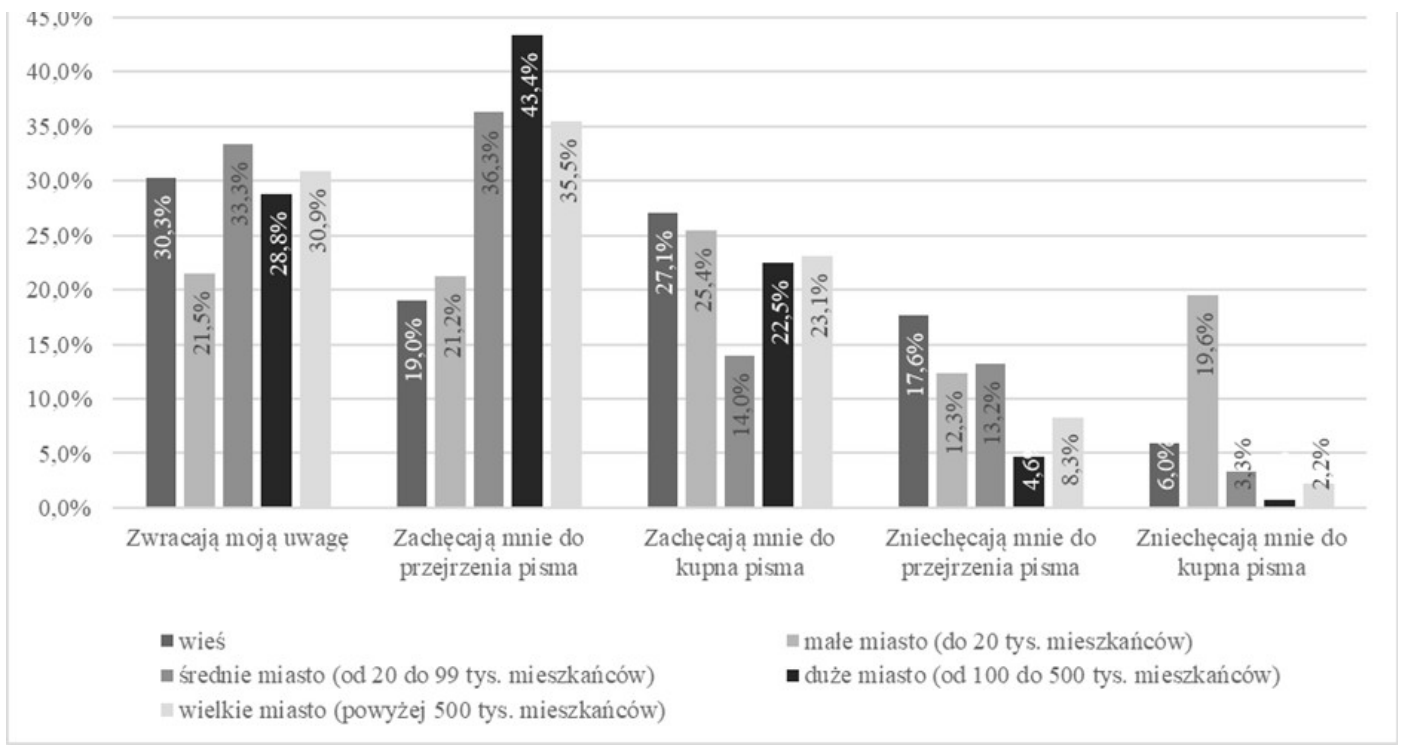

Rysunek 8. Reakcje odbiorców na tematy okładkowe polskich magazynów (dane szczegółowe - miejsce zamieszkania). Źródło: opracowanie własne na podstawie badań przeprowadzonych na ogólnopolskiej próbie liczącej N=1094 osób, dobranej z panelu Ariadna metodą CAWI. Odpowiadający: wszyscy badani. 


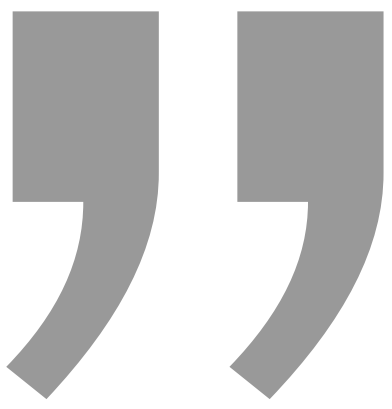

W przypadku kategorii miejsca zamieszkania warto podkreślić trzy tendencje: po pierwsze, w ogólnym rozrachunku najsłabiej wypada tutaj bezpośredni element prosprzedażowy. Po drugie - w ośrodkach powyżej 20000 mieszkańców ważną rolę pełni przegląadanie pism pod wpływem okładek, oznaczające, że odbiorcy faktycznie praǵną chociażby pobieżnie zapoznać się z treścią tytułu. Po trzecie - poziom potwierdzeń zakupu pism w porównaniu do przeglądania ich zawartości jest zdecydowanie niższy, co skłania do postawienia pytania o jakość tejże zawartości i dopasowanie jej do grupy docelowej.

Mieszkańcy małych miast deklarują wysoki poziom zniechęcenia pod wpływem okładek, zarówno przy przeglądaniu, jak i zakupie (łącznie ponad 30\%). Co ciekawe, badani z tej grupy nieco częściej pisma kupują $(25,4 \%)$ niż je np. przeglądają, ale tak czy tak wynik ten jest gorszy od łącznego rezultatu prezentującego negatywne nastawienie do omawianego zjawiska. Można więc założyć, że ta grupa bywa dość problematyczna dla działalności wydawniczej. Z kolei rezydenci średnich miast nie kupują pism pod wpływem tematów okładkowych (zaledwie 14\% odpowiedzi), częściej zaś je zauważają i przeglądają (ponad 36,3\%). Mieszkańcy dużych miast nie są negatywnie nastawieni do tematów okładkowych, chociaż odpowiedzi związane z prosprzedażowym oddziaływaniem tego elementu magazynu wskazują na jego umiarkowaną skuteczność (ponad 22,5\%). Polacy wskazali, że pod wpływem tematów okładkowych najchętniej pisma przeglądają (aż 43,4\%). Warto więc zastanowić się - skoro między przeglądaniem a kupnem istnieje taka różnica - czy zawartość pisma nie osłabia wyników sprzedaży? Mieszkańcy wielkich miast także nie zniechęcają się tematami okładkowymi, ale i w tym przypadku widać wyraźną różnicę między wynikami potwierdzającymi przeglądanie magazynu oraz jego zakup (jest ona mniejsza niż w przypadku dużych miast, ale nadal zauważalna).

W przypadku kategorii miejsca zamieszkania warto podkreślić trzy tendencje: po pierwsze, w ogólnym rozrachunku najsłabiej wypada tutaj bezpośredni element prosprzedażowy. Po drugie - w ośrodkach powyżej 20000 mieszkańców ważną rolę pełni przeglądanie pism pod wpływem okładek, oznaczające, że odbiorcy faktycznie pragną 


\section{OBLICZA MEDIÓW}

chociażby pobieżnie zapoznać się z treścią tytułu. Po trzecie - poziom potwierdzeń zakupu pism w porównaniu do przeglądania ich zawartości jest zdecydowanie niższy, co skłania do postawienia pytania o jakość tejże zawartości i dopasowanie jej do grupy docelowej.

\section{Zakończenie}

W niniejszym artykule zrealizowano wszystkie założone cele. Po pierwsze, wskazano rolę (informacyjną i promocyjną) oraz formę (graficzną, zdjęciową i tekstową) tematów okładkowych. Po drugie, przedstawiono wyniki ankiety zgodne z zakresem badawczym, który nakreślono w tytule tekstu. Tu autorka skoncentrowała się na dwóch wątkach, najpierw przedstawiając dane uśrednione, a następnie szczegółowe (ujęte w kontekście demograficznym: wieku, płci, wykształcenia i miejsca zamieszkania respondentów). Tematy okładkowe zbadała więc w kontekście:

- elementów składowych (podejścia respondentów do fotografii, grafik i tekstów z założeniem, że ze względu na objętość prezentowanych danych, szczegółową analizę stosunku Polaków do pozostałych części składowych okładek autorka przedstawi w innym artykule);

- reakcji odbiorców (od zwrócenia uwagi na pismo, przez przejrzenie, zachęcenie do kupna, aż pełne zniechęcenie do zaznajomienia się z magazynem);

Autorka potwierdziła słuszność pierwszej hipotezy, która brzmiała: „Odbiorcy odmiennie traktują elementy składowe tematów okładkowych (to jest tekst, grafikę i zdjęcia)". Zdecydowany prym wiodą tu komponenty kultury obrazkowej, które dominują nad słowem pisanym. W zależności od grupy docelowej udział poszczególnych elementów tematów okładkowych nieco się zmienia, ale tekst ani razu nie staje na szczycie któregokolwiek zestawienia.

Kolejną hipotezę także zweryfikowano pozytywnie: okazało się, że kategorie demograficzne (takie jak wiek, płeć, zamieszkanie, wykształcenie) istotnie wpływają na preferencje względem tematów okładkowych. W dwóch podjętych wątkach badawczych wyniki różnicują się i są generalnie odmienne od danych uśrednionych, co wskazuje na konieczność daleko idącego dopasowywania kompozycji tematów okładkowych do preferencji zróżnicowanych grup odbiorczych.

W przypadku trzeciej hipotezy - „Tematy okładkowe mają znacznie w prowadzeniu działalności biznesowej wydawców" - widać, że nie przekładają się one jednoznacznie na odpowiedzi potwierdzające zakup pisma pod ich wpływem. Jednak negatywne preferencje odbiorców (wykazujące ich zniechęcenie) to także ważna informacja, podpowiadająca czego - w zależności od danej grupy docelowej - nie należy eksponować na okładkach.

Równie ważne są jednak pytania o zwracanie uwagi i przeglądanie pism pod wpływem tematów okładkowych: w dużej mierze od nich przecież zależy, czy potencjalny nabywca (po zaznajomieniu się z tytułem) stanie się realnym czytelnikiem ${ }^{16}$. Patrząc

16 O tym, że widoczność w magazynach jest ważniejsza od przeczytania (,„ponieważ jeśli czegoó się nie spostrzeże, to się tego nie kupi”) przekonywali np. David E. Sumner, Shirrel Rhoades. Por. D. E. Sumner, S. 
na przedstawione wyniki - w najlepszych przypadkach oscylujące w okolicach średnio 30-40\% wskazań - trzeba stwierdzić, że pominięcie tej liczby pozytywnych odpowiedzi byłoby nierozsądne z biznesowego punktu widzenia. Nawet, jeżeli ich oddziaływanie nie przekłada się od razu na zakup, to jednak prowadzi do zaznajomienia się z tytułem prasowym: to zaś może skutkować zwiększoną sprzedażą w przyszłości. W takim kontekście należy uznać, że trzecią hipotezę - tym razem w kontekście pożądanego oddziaływania tematów okładkowych - także zweryfikowano pozytywnie.

\section{BIBLIOGRAFIA:}

GPCodziennie z 16.05.2017 r., https://www.facebook.com/GPCodziennie/, dostęp 18.05.2017 r.

GPtygodnik z 16.05.2017 r., https://twitter.com/GPtygodnik, dostęp 18.05.2017 r.

Grow G., Magazine Covers and Cover Lines: An Illustrated History, "Journal of Magazine \& New Media Research", Vol. 5, No. 1, 2002, s. 4 i 16.

Jupowicz-Ginalska A., Zadania okładek współczesnych magazynów drukowanych, „Rocznik Bibliologiczno-Prasoznawczy” 2017 nr 20 - W DRUKU

Fijewska M., "Jesteście podli!". Okładka z Magdaleną Żuk wywołała burzę, Wp.pl z 17.05.2017, http://wiadomosci.wp.pl/jestescie-podli-okladka-zmagdalena-zuk-wywolala-burze-6123340667676801a, dostęp 18.05 . $2017 \mathrm{r}$.

Johnson S., Prijatel P., Magazine Publishing, Lincolnwood, IL 2000.

McCracken E., Decoding Women's Magazines: From Mademoiselle to Ms., Houndmills - Basingstoke, Hampshire - Londyn 1993, s. 13.

Nocne kluby, w których bywają politycy PO.... To niewiarygodne, ale "Gazeta Polska" upolityczniła śmierć Magdaleny Żuk, NaTemat.pl z 17.05.2017 r., http://natemat.pl/208251,nocne-kluby-w-ktorych-bywaja-politycy-po-to-niewiarygodne-ale-gazeta-polska-upolitycznila-smierc-magdaleny-zuk, dostęp 18.05.2017 r.)

Perchla-Włosik A., Wardzała J., Młodzi członkowie gospodarstw domowych jako konsumenci mediów masowych w świetle badań jakościowych, „Zeszyty Naukowe Wyższej Szkoły Bankowej we Wrocławiu” 2015 z. 3, s. 401.

Sumner D. E., Miller H. G., Feature and Magazine Writing: Action, Angle and Anecdotes, Chichester WS 2009, s. 81.

Sumner D. E., Rhoades S., Magazines: A Complete Guide to the Industry, Nowy Jork 2006, s. 47-54.

Szylko-Kwas J., Fotografią po oczach. O fotografii na pierwszej stronie „Gazety Wyborczej” i „Rzeczpospolitej”, „Studia Medioznawcze” 2011 z. 44, s. 139 i 141.

Rhoades, Magazines: A Complete Guide..., dz. cyt., s. 55. 


\section{OBLICZA MEDIÓW}

Thompson L., Cover Story: Have You Got What It Takes to Be a Magazine Editor?, Mankato MN 2009

Waligóra L., Jak zrobić dobrą jedynkę?, Juniormedia.pl (brak daty opubl.), http://www.juniormedia.pl/wp-content/uploads/2013/07/Jakzrobicdobrajedynke.pdf (dostęp 18.05.2017 r.)

White J. E., Meet Generation Z: Understanding and Reaching the New PostChristian World, Waszyngton 2017.

Williams A., Move over, Millennials, here comes Generation Z, The New York Times.com z 18.09.2015 r.,

https://www.nytimes.com/2015/09/20/fashion/move-over-millennialshere-comes-generation-z.html?_r=0 (dostęp 19.05.2017 r.).

http://www.gazetapolska.pl dostęp 18.05.2017 r.

https://panelariadna.pl/userpanel.php, dostęp: 15.05.2017.

\section{OAUTORCE:}

Dr Anna Jupowicz-Ginalska - jedna z nielicznych badaczek w Polsce, specjalizująca się w tematyce marketingu środków przekazu. W obszarze jej zainteresowań naukowych pozostają także: wspótczesne trendy w komunikacji marketingowej, opowieść transmedialna, popkultura, marketing show biznesu i manipulacja.

Jest autorką licznych publikacji naukowych na temat marketingu mediów, a jej książka „Marketing medialny” otrzymała nagrodę główną w konkursie „Złote Skrzydła Dziennika Gazety Prawnej i KPMG 2011" (była to pierwsza kompletna publikacja z marketingu medialnego w Polsce).

Aktywnie uczestniczy w konferencjach ogólnopolskich i międzynarodowych, pojawia się $w$ mediach $w$ roli ekspertki z zakresu mediów i popkultury (m.in. w Polsat News 2, Polsat, Polsat Cafe, TVP1, „Rzeczpospolita”, „Party”). Pozostaje także czynna zawodowo w sferze praktycznej: od 15 lat jest związana $z$ branżą promocyjną (głównie public relations). Pracowała m.in. w agencjach PR, korporacjach medialnych $i$ administracji publicznej. Od 2010 do 2017 roku pelniła obowiązki Pełnomocnika Dziekana ds. Promocji Wydziału Dziennikarstwa i Nauk Politycznych UW oraz Wydziału Dziennikarstwa, Informacji i Bibliologii UW, m.in. organizując najważniejsze wydarzenia budujące wizerunek Wydziału.Kontakt:a.ginalska@uw.edu.pl. 